Reprod. Nutr. Dévelop. 1980, 20 (1 A), 197-201.

\title{
Induction of autumn moult in mink (Mustela vison Peale and Beauvois) with melatonin
}

\author{
par D. ALLAIN, J. ROUGEOT
}

Laboratoire des Peloges, Toisons ef Fourrures

I.N.R.A., 78350 Jouy-en-Josas, France.

Summary. Adult female mink, living in natural conditions of temperature and photoperiod, were treated by melatonin implants in mid-July, when the summer coat was in its resting stage. As a result, a moult was induced 5 to 6 weeks before the normal time ; its showed the characteristics of an autumn moult as observed by the gradient of hair changes over the body and the high number of hair follicles per bundle (47 p. 100 more than in the summer coat). The winter coats produced in this way were mature in the early days of October, i.e. 6 to 7 weeks before those of the control group.

\section{Introduction.}

It has been known for several decades that the seasonal coat moult in mammals is regulated by the photoperiod (Bissonnette, 1935 ; Bissonnette and Wilson, 1939 ; Basset ef al., 1944 ; Belyaev and Utkin, 1949 ; Hammond Jr., 1952 ; Rougeot, 1957). The spring moult produced a thin flat coat and the autumnal one a thick, long winter coat, each moult being induced by a different photoperiod (Harvey and McFarlane, 1958). Although numerous studies have been made on the hormonal regulation of the hair follicle cycle (Mohn, 1958 ; Ebling and Johnson, 1964 ; Al Khateeb and Johnson, 1971), no satisfactory explanation has been furnished for the induction of these moults or for the neuro-endocrine mechanisms of the hypothalamo-pituitary system triggering them.

Up to now, melatonin which plays a role in the regulation of seasonally-dependent functions that are controlled by the photoperiod, is the only hormone demonstrated to induce moulting. Rust and Meyer (1969) using melatonin implants in the stoat, obtained renewal of the coat, white hair replacing the pigmented pelage by the inhibitory action of melatonin on melanocyte-stimulating hormone (MSH). Other explanations were suggested later (Hoffmann, 1973 ; Logan and Weatherhead, 1978). However Rust and Meyer did not go into detail on the induction of the moult which they induced, and gave no other data in coat composition or structure which would aid in defining the type of coat obtained. 
We thus repeated the experiment on mink which have a pigmented coat through the year in order to verify if melatonin induces a moult and to determine the nature of the resultant coat.

\section{Materials and methods.}

The experiment began on July 13 when the growth of the summer coat was finished and was in its resting stage. Two groups of 5 pastel females that had been born in May 1977 and reared conventionnally in wire cages under a shelter in the natural environmental conditions that prevailed in our region were used. Each animal weighed approximately $1 \mathrm{~kg}$. Melatonin ( $\mathrm{N}$-acetyl-5-methoxytryptamine, Fluka, Buchs, Switzerland) was introduced by Silastic $5 \mathrm{~cm}$ long implants (no. 602-235 ; i.d., $1.47 \mathrm{~mm}$; o.d., $1.96 \mathrm{~mm}$; Dow Corning Corp., Midland, Michigan USA). One implant was deposited in the panniculus adiposus of the dorsal skin of each of the treated animals; the implants contained melatonin in a range of 47.7 to $52.3 \mathrm{mg}$. The controls were given melatonin-free implants in the same way. When the next moult was finished, the implants were withdrawn, dried and weighed to determine the quantity of melatonin diffused. The changes of the pelage were observed macroscopically and microscopically.

Macroscopically, the progress of moulting was checked by separating the hair to observe the extension of pigmentation over the skin : this pigmentation is due to the renewal of melanogenesis in hair follicles in early anagen and is seen through the transparent skin. Melanogenesis stops at the end of hair growth, and when all the hair follicles of an area of skin are in telogen the skin then becomes white again. In mink (Basset and Llewellyn, 1949) the autumnal moult begins at the end of August at the tip of the tail when the skin looks blue; the pigmentation then progresses anteriorly and in the ventro-dorsal direction ending on the back so that the whole skin is blue at the end of September. Then, as the hair follicles proceed to telogen, the skin becomes gradually white following the same gradient, so that the maturity of the coat is finally established at the end of November. On the other hand, the spring moult progresses posteriorally and usually does not affect the tail.

For the microscopical observations, skin samples of $1 / 3 \mathrm{~cm}^{2}$ were taken from the side by biopsy with a circular trephine every 7 days. The skin pieces were treated according to the classical histological methods, the sections of $7 \mu \mathrm{m}$ being cut parallel to the epidermis. The hair density was determined with the aid of a projection microscope by counting the number of hair follicles contained in each follicular bundle. In the mink, these bundles are easily identified and form well-defined units belonging to a single permanent hair canal (counting the number of hair or hair follicles per unit area of skin surface is uncertain, since skin elasticity introduces significant errors). The counts were only taken in telogen phase, when the hair follicles are very distinct with only one hair inside.

\section{Results.}

In both groups, the moult began at the tip of the fail, progressed over all the body, ending on the back, according to the characteristic gradient of the autumnal moult. 
But in the treated mink (fig. 1) the moult began at the end of July, 2 or 3 weeks after the implants were given, or 5 weeks earlier than in the controls, where the moult started normally at the end of August. In the treated animals the coat was mature in the first week of October, or 6 to 7 weeks earlier than in the controls where the coat maturity was normally established at the end of November.
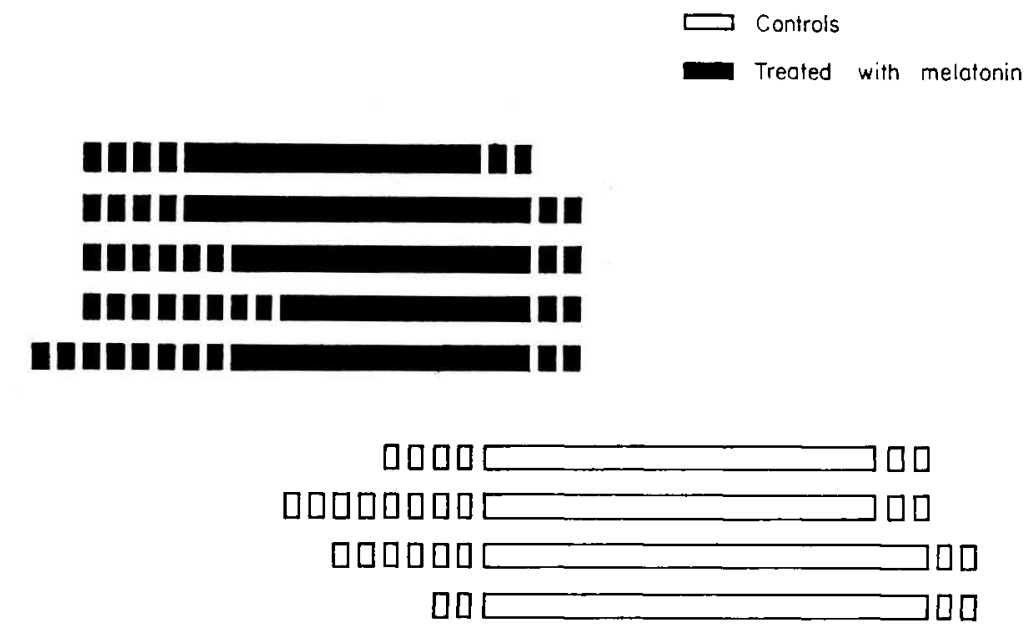

$\overbrace{\text { July }}^{\text {Implant timing }(13 / 7)}$ August $T$ September $T$ October 1 November December

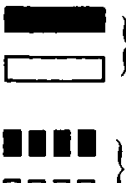

Pigmented (blue) skin all over the body (peloge in anagen) विएव

Pigmented (blue) skin present only on part of the body (beginning or end of the moult)

FIG. 1. - Effects of melatonin on timing and duration of the autumn moult in mink.

\section{TABLE 1}

Number of hair follicles in a bundle unit depending on one hoir canal after aufumn moult and after melatonin-induced moult in mink (mean \pm SEM)

\begin{tabular}{cccccc}
\hline & Controls & & Melatonin-treated \\
\hline $\begin{array}{c}\text { Summer coat } \\
\text { July } 13\end{array}$ & $\begin{array}{c}\text { Winter coat } \\
\text { November } 30\end{array}$ & $\begin{array}{c}\text { p. } 100 \\
\text { increase }\end{array}$ & $\begin{array}{c}\text { Summer coat } \\
\text { July } 13\end{array}$ & $\begin{array}{c}\text { Induced coat } \\
\text { October } 5\end{array}$ & $\begin{array}{c}\text { p. } 100 \\
\text { increase }\end{array}$ \\
\hline $10.4 \pm 0.8$ & $15.4 \pm 1.0 * *$ & +47.6 & $13.1 \pm 1.5$ & $19.2 \pm 0.7 * *$ & +46.6
\end{tabular}

** Highly significant $(P<0.001)$ in relation to summer coat. 
When the maturity of the pelages was completed the implants were withdrawn and counts of hair follicles in telogen performed.

The weights of diffused melatonin were found in the range of 2.0 to $2.9 \mathrm{mg}$ per animal, giving a daily dose in the range of 20 to $30 \mu \mathrm{g} / \mathrm{d}$.

The number of hair follicles per bundle (table 1) increased significantly in identical proportions in both groups : 47.6 p. 100 in the treated animals and 46.6 p. 100 in the controls. The fact that the treated mink had a lower hair follicle density than the controls ( 2.7 follicles less per bundle in July ; 3.3 follicles less in October) did not affect the rate of increase.

\section{Discussion.}

Melatonin administered by implants in the long days induced an autumnal moult in mink producing a winter coat. Thus we possess one element of the neuroendocrine mechanism controling photoperiod-dependent moult. However the mode of action of melatonin and of the pineal gland is still unknown. We can only suggest that the results of our limited observations using melatonin do not contradict those obtained on the testicular activity in hamsters : implants of melatonin produce opposite effects to those due to the existing photoperiod (Turek, 1978 ; Bittman, 1978). But we must understand how continuous melatonin diffusion interferes with endogenous melatonin (Goldman et al., 1979) which has a definite circadian secretion rhythm with a peak of several hours in the night (Panke ef al., 1979) ; we must verify the importance of the level of the dose itself (ours was half of that used in male hamsters) as well as the conditions of its application (way, time, frequency).

Reçu en ooût 1979. Accepté en septembre 1979.

Résumé. Des visons femelles adultes, élevés en conditions naturelles de température et de photopériode, furent traités par des implants de mélatonine à la mi-juillet, lorsque le pelage d'été se trouve au stade de repos. Il en résulte l'induction précoce d'une mue, 5 à 6 semaines avant l'époque normale, offrant toutes les caractéristiques d'une mue d'automne tant par le gradient de progression sur le corps que par le nombre élevé de follicules pileux mis en activité (47 p. 100 de plus que pour le pelage d'été). Les pelages d'hiver ainsi obtenus atteignirent leur maturité dès le début d'octobre, soit 6 à 7 semaines avant ceux des témoins.

\section{References}

BASSET F. C., LLEWELLYN L. M., 1949. The molting and fur growth pattern in the adult mink. Am. Midl. Nat., 42, 751-756.

BASSET F. C., PEARSON O. P., WILKE F., 1944. The effect of artificially-increased length of day on molt, growth, and priming of silver fox pelts. J. exp. Zool., 96, 77-83.

BELYAEV D. K., UTKIN L. G., 1949. Influence de la réduction de la durée de l'éclairement sur les délais de la formation de la fourrure chez le renard (en russe). Karakulevod. Zverovod., 2, 59-62.

BISSONNETTE T. H., 1935. Relations of hair cycles in ferrets to changes in the anterior hypophysis and light cycles. Anat. Rec., 63, 159-168.

BISSONNETTE T. H., WILSON E., 1939. Shortening daylight periods between May 15 and September 12 and the pelt cycle of the mink. Science, 89, 418-419. 
BITTMAN E. L., 1978. Melatonin prevents refractoriness to short day in male hamsters. Proc. Soc. exp. Biol. Med., 158, 359-362.

EBLING F. J., JOHNSON E., 1964. The action of hormones on spontaneous hair growth cycles in the rat. J. Endocrinol., 29, 193-201.

GOLDMAN B., HALL V., HOLLISTER C., ROYCHOUDHURY P., TAMARKIN L., WESTROM W., 1979. Effects of melatonin on the reproductive system in infact and pinealeciomized male hamsters maintained under various photoperiods. Endocrinology, 104, 82-88.

HAMMOND J. Jr., 1952. Control of reproductive and pelt changes in ferrets : some experiments with animals kept entirely upon artificial light. J. agric. Sci., 42, 293-303.

HARVEY N. E., McFARLANE W. V., 1958. The effects of day length on the coat-shedding cycles, body weight, and reproduction of the ferret. Austr. J. biol. Sci., 11, 187-199.

HOFFMANN K., 1973. The influence of photoperiod and melatonin on testis size, body weight and pelage color in the Djungarian hamster (Phodopus sungorus). J. comp. Physiol., 85, 267-282.

KHATEEB A. AL, JOHNSON E., 1971. Seasonal changes of pelage in the vole (Microfus agrestis). Gen. comp. Endocrinol., 16, 217-235.

LOGAN A., WEATHERHEAD B., 1978. Pelage color cycles and hair follicle tyronisase activity in the Siberian hamster. J. Invest. Dermatol., 71, 295-298.

MONH M. P., 1958. The effects of different hormonal states on the growth of hair in rats, 335-398. In MONTAGNA W., ELLIS R. A., The biology of hair growth. Acad. Press, New York.

PANKE E. S., ROLLAG M. D., REITER R. J., 1979. Pineal melatonin concentrations in the Syrian hamster. Endocrinology, 104, 194-197.

ROUGEOT J., 1957. Action saisonnière de la durée quotidienne d'éclairement sur la mue de certaines fibres de la toison de la race ovine limousine. C. $R$. Soc. Biol., 51, 834-837.

RUST C. C., MEYER R. K., 1969. Hair color, molt, and testis size in male, short-tailed weasels treated with melatonine. Science, 165, 921-922.

TUREK F. W., LOSEE S. H., 1978. Melatonin-induced testicular growth in golden hamsters maintained in short days. Biol. Reprod., 18, 299-305. 